\title{
Maternal Hypothyroidism-Developing Dyslipidemia: What is the Connection?
}

\author{
Ahmed R.G. \\ Division of Anatomy and Embryology, Zoology Department, Faculty of Science, Beni-Suef University, \\ Beni-Suef, Egypt.
}

*Corresponding Author: Ahmed R.G., Division of Anatomy and Embryology, Zoology Department, Faculty of Science, Beni-Suef University, Beni-Suef, Egypt

\section{COMMENTARY}

Maternal thyroid hormones (THs) are essential for the developing newborns(El-bakry et al., 2010;Ahmed, 2011, 2012a,b, 2013, 2014, 2015a-c, 2016a-d, 2017a-v, 2018a-s;Ahmed and Ahmed, 2012; Ahmed et al., 2013a,b, 2014, 2015a,b, 2018a,b; Ahmed and Incerpi, 2013;Van Herck et al., 2013; Ahmed and El-Gareib, 2014,Incerpi et al., 2014; Candelotti et al., 2015; De Vito et al., 2015; El-Ghareeb et al., 2016; Ahmed and El-Gareib, 2017), especially the thermogenesis, lipogenesis, and lipid contents (fatty acids composition and phospholipids in the cell membrane) (Prasad \& Kumar, 2005; Catargi et al., 2009; Zhu and Chang, 2010; Saleh, 2015).

On the other hand, several investigations have revealed the link between the hypothyroidism and dyslipidemia (Stone, 1994; Beyer et al., 1998; Tsimihodimos et al., 1999; Celiket al., 2012; BenettiPinto et al., 2013; Raza and Mahmood, 2013). In subclinical hypothyroidism, numerous studies have reported that dyslipidemia might be accompanied by the following: (1) elevations in the levels of triglycerides (TGs) (Milionis et al., 2005; Toruner et al., 2008); (2) reductions in the levels of highdensity lipoprotein cholesterol (HDL-C) (Erdem et al., 2008); (3) elevations in the levels of lowdensity lipoprotein cholesterol (LDL-C) and total cholesterol (TC) (Tanis et al., 1996; Danese et al., 2000; Luboshitzky et al., 2002; Jung et al., 2003; Monzani et al., 2004; Walsh et al., 2005; Erem, 2006; Duman et al., 2007); (4) decrease the ratio of cholesterol/TGs (Brenta et al., 2007); (5) increase the levels of apolipoprotein B (ApoB) (Efstathiadou et al., 2001); and (6) increase the levels of lipoprotein(a) [Lp(a)] and apolipoprotein(a) [apo(a)] (Kung et al., 1995; Efstathiadou et al., 2001; Caraccio et al., 2002; Milionis et al., 2003; Iqbal et al., 2006). More importantly, the above disruptions can increase the risk of the cardiovascular diseases (Raza and Mahmood, 2013). In fact, Hueston and Pearson (2004) observed that the subclinical hypothyroidism did not has any effect on the lipid profile if we adjust the race, sex, age and use of lipid-lowering drugs. In addition, Knudsen et al (2005) recorded that any change in the activities of the thyroid gland can be harmful to the body mass index (BMI) and cause obesity. On the other hand, the presence of insulin resistance can reinforce the effect of hypothyroidism on the lipid profile (Bakker et al., 2001; Chubb et al., 2005).

On the basis of these observations, I hypothesized the following: (1)THs, perhaps of maternal origin, play vital roles in the homeostasis of the fetal lipid profile; (2) the maternal thyroid disorders (hypothyroidism) may perturb the lipid homeostasis (contents, metabolism and distributions) in liver and adipose tissues during the gestation and lactation; (3) the maternal hypothyroidism may cause fetal/neonatal dyslipidemia; and (4) the maternal hypothyroidism may delay the fetal/neonatal development. Thus, adjusting the levels of maternal, fetal and neonatal THs and thyroid-stimulating hormone (TSH) can easily prevent this disturbance during the gestation and lactation. Future studies are required to understand the connection between the genomic and non-genomic actions of THs during the abnormal conditions (hypothyroidism or hyperthyroidism during the gestation and lactation) and fetal dyslipidemia. This view will assist to prevent not only the thyroid dysfunction during the critical developmental periods but also the cardiovascular disease and obesity (predominant diseases in our life). Thus, the association between the molecular and developmental investigations is warranted. 


\section{REFERENCES}

[1] Ahmed, O.M., Abd El-Tawab, S.M., Ahmed, R.G., 2010. Effects of experimentally induced maternal hypothyroidism and hyperthyroidism on the development of rat offspring: I- The development of the thyroid hormones-neurotransmitters and adenosinergic system interactions. Int. J. Dev. Neurosci. 28, 437 454.

[2] Ahmed, O.M., Ahmed, R.G., 2012. Hypothyroidism. In A New Look At Hypothyroidism. Dr. D. Springer (Ed.), ISBN: 978-953-51-0020-1), In Tech Open Access Publisher, Chapter 1, pp. 1-20.

[3] Ahmed, O.M., Ahmed, R.G., El-Gareib, A.W., El-Bakry, A.M., Abd El-Tawaba, S.M., 2012. Effects of experimentally induced maternal hypothyroidism and hyperthyroidism on the development of rat offspring: II-The developmental pattern of neurons in relation to oxidative stress and antioxidant defense system. Int. J. Dev. Neurosci. 30, 517-537.

[4] Ahmed, O.M., El-Gareib, A.W., El-bakry, A.M., Abd El-Tawab, S.M., Ahmed, R.G., 2008. Thyroid hormones states and brain development interactions. Int. J. Dev. Neurosci. 26(2), 147-209. Review.

[5] Ahmed, R.G., 2011. Perinatal 2, 3, 7, 8-tetrachlorodibenzo-p-dioxin exposure alters developmental neuroendocrine system. Food Chem. Toxicology, 49, 1276-1284.

[6] Ahmed, R.G., 2012a. Maternal-newborn thyroid dysfunction. In the Developmental Neuroendocrinology, pp. 1-369. Ed R.G. Ahmed. Germany: LAP LAMBERT Academic Publishing GmbH \& Co KG.

[7] Ahmed, R.G., 2012b. Maternal-fetal thyroid interactions, Thyroid Hormone, Dr. N.K. Agrawal (Ed.), ISBN: 978-953-51-0678-4, In Tech Open Access Publisher, Chapter 5, pp. 125-156.

[8] Ahmed, R.G., 2013. Early weaning PCB 95 exposure alters the neonatal endocrine system: thyroid adipokine dysfunction. J. Endocrinol. 219 (3), 205-215.

[9] Ahmed, R.G., 2014. Editorial: Do PCBs modify the thyroid-adipokine axis during development? Annals Thyroid Res. 1(1), 11-12.

[10] Ahmed, R.G., 2015a. Chapter 1: Hypothyroidism and brain development. In advances in hypothyroidism treatment. Avid Science Borsigstr.9, 10115 Berlin, Berlin, Germany. Avid Science Publications level 6, Melange Towers, Wing a, Hitec City, Hyderabad, Telangana, India. pp. 1-40.

[11] Ahmed, R.G., 2015b. Hypothyroidism and brain developmental players. Thyroid Research J. 8(2), 1-12.

[12] Ahmed, R.G., 2015c. Editorials and Commentary: Maternofetal thyroid action and brain development. J. of Advances in Biology; 7(1), 1207-1213.

[13] Ahmed, R.G., 2016a. Gestational dexamethasone alters fetal neuroendocrine axis. Toxicology Letters, 258, 46-54.

[14] Ahmed, R.G., 2016b. Neonatal polychlorinated biphenyls-induced endocrine dysfunction. Ann. Thyroid. Res. 2 (1), 34-35.

[15] Ahmed, R.G., 2016c. Maternal iodine deficiency and brain disorders.Endocrinol.Metab.Syndr.5, 223.http://dx.doi.org/10.4172/2161-1017.1000223.

[16] Ahmed, R.G., 2016d. Maternal bisphenol A alters fetal endocrine system: Thyroid adipokine dysfunction. Food Chem. Toxicology, 95, 168-174.

[17] Ahmed, R.G., 2017a. Developmental thyroid diseases and GABAergic dysfunction. EC Neurology 8.1, 02-04.

[18] Ahmed, R.G., 2017b. Hyperthyroidism and developmental dysfunction.Arch Med. 9, 4.

[19] Ahmed, R.G., 2017c. Anti-thyroid drugs may be at higher risk for perinatal thyroid disease. EC Pharmacology and Toxicology 4.4, 140-142.

[20] Ahmed, R.G., 2017d. Perinatal hypothyroidism and cytoskeleton dysfunction. EndocrinolMetabSyndr 6, 271.doi:10.4172/2161-1017.1000271

[21] Ahmed, R.G., 2017e.Developmental thyroid diseases and monoaminergic dysfunction. Advances in Applied Science Research 8(3), 01-10.

[22] Ahmed, R.G., 2017f.Hypothyroidism and brain development.J. Anim Res Nutr.2 (2), 13.

[23] Ahmed, R.G., 2017g. Antiepileptic drugs and developmental neuroendocrine dysfunction: Every why has A Wherefore? Arch Med 9(6), 2.

[24] Ahmed, R.G., 2017h. Gestational prooxidant-antioxidant imbalance may be at higher risk for postpartum thyroid disease. EndocrinolMetabSyndr 6, 279. doi:10.4172/2161-1017.1000279.

[25] Ahmed, R.G., 2017i. Synergistic actions of thyroid-adipokines axis during development. EndocrinolMetabSyndr 6, 280.doi:10.4172/2161-1017.1000280.

[26] Ahmed, R.G., 2017j. Thyroid-insulin dysfunction during development. International Journal of Research Studies in Zoology 3(4), 73-75. DOI: http://dx.doi.org/10.20431/2454-941X.0304010. 
[27] Ahmed, R.G., 2017k. Developmental thyroid diseases and cholinergic imbalance. International Journal of Research Studies in Zoology 3(4), 70-72. DOI: http://dx.doi.org/10.20431/2454-941X.0304009.

[28] Ahmed, R.G., 20171. Thyroid diseases and developmental adenosinergic imbalance.Int J ClinEndocrinol 1(2), 053-055.

[29] Ahmed, R.G., 2017m.Maternal anticancer drugs and fetal neuroendocrine dysfunction in experimental animals. EndocrinolMetabSyndr 6, 281.doi:10.4172/2161-1017.1000281.

[30] Ahmed, R.G., 2017n. Letter: Gestational dexamethasone may be at higher risk for thyroid disease developing peripartum. Open Journal of Biomedical \& Life Sciences (Ojbili) 3(2), 01-06.

[31] Ahmed, R.G., 2017o.Deiodinases and developmental hypothyroidism. EC Nutrition 11.5, 183-185.

[32] Ahmed, R.G., 2017p.Maternofetal thyroid hormones and risk of diabetes. Int. J. of Res. Studies in Medical and Health Sciences 2(10), 18-21.

[33] Ahmed, R.G., 2017r.Association between hypothyroidism and renal dysfunctions. International Journal of Research Studies in Medical and Health Sciences 2(11), 1-4.

[34] Ahmed, R.G., 2017s.Maternal hypothyroidism and lung dysfunction. International Journal of Research Studies in Medical and Health Sciences 2(11), 8-11.

[35] Ahmed, R.G., 2017t.Endocrine disruptors; possible mechanisms for inducing developmental disorders. International journal of basic science in medicine (IJBSM) 2(4), 157-160.

[36] Ahmed, R.G., 2017u.Maternal thyroid hormones trajectories and neonatal behavioral disorders. ARC Journal of Diabetes and Endocrinology 3(2), 18-21.

[37] Ahmed, R.G., 2017v.Maternal thyroid dysfunction and neonatal cardiac disorders. Insights Biol Med. 1, 092-096.

[38] Ahmed, R.G., 2018a. Maternal hypothyroidism and neonatal testicular dysfunction. International Journal of Research Studies in Medical and Health Sciences 3(1), 8-12.

[39] Ahmed, R.G., 2018b. Maternal hypothyroidism and neonatal depression: Current perspective. International Journal of Research Studies in Zoology 4(1), 6-10. DOI: http://dx.doi.org/10.20431/2454-941X.0401002.

[40] Ahmed, R.G., 2018c. Non-genomic actions of thyroid hormones during development. App ClinPharmacolToxicol: ACPT-108. DOI: 10.29011/ACPT-109. 100008.

[41] Ahmed, R.G., 2018d. Maternal thyroid function and placental hemodynamics. ARC Journal of Animal and Veterinary Sciences 4(1), 9-13. DOI: http://dx.doi.org/10.20431/2455-2518.0401002.

[42] Ahmed, R.G., 2018e.Interactions between thyroid and growth factors during development. ARC Journal of Diabetes and Endocrinology 4(1), 1-4. DOI: http://dx.doi.org/10.20431/2455-5983.0401001.

[43] Ahmed, R.G., 2018f. Maternal thyroid hormones and neonatal appetite. ARC Journal of Nutrition and Growth 4(1), 18-22. DOI: http://dx.doi.org/10.20431/2455-2550.0401005.

[44] Ahmed, R.G., 2018g. Genomic actions of thyroid hormones during development. ARC Journal of Diabetes and Endocrinology 4(1), 5-8. DOI: http://dx.doi.org/10.20431/2455-5983.0401002.

[45] Ahmed, R.G., 2018h. Dysfunction of maternal thyroid hormones and psychiatric symptoms. American Research Journal of Endocrinology. 2(1), 1-6.

[46] Ahmed, R.G., 2018i. Is there a connection between maternal hypothyroidism and developing autism spectrum disorders? ARC Journal of Neuroscience 3(1), 5-8. DOI: http://dx.doi.org/10.20431/2456057X.0301002.

[47] Ahmed, R.G., 2018j.Maternal thyroid dysfunctions and neonatal bone maldevelopment.American Research Journal of Endocrinology (In press) xx-xxx.

[48] Ahmed, R.G., 2018k. Maternal thyroid disorders and risk of neonatal seizure: Current perspective. ARC Journal of Neuroscience 3(1), 21-25. DOI: http://dx.doi.org/10.20431/2456-057X.0301004

[49] Ahmed, R.G., 20181. Gestational dioxin acts as developing neuroendocrine-disruptor. EC Pharmacology and Toxicology 6.3, 96-100.

[50] Ahmed, R.G., 2018m.Maternal thyroid dysfunction and risk of neonatal stroke. ARC Journal of Animal and Veterinary Sciences 4(1), 22-26. DOI: http://dx.doi.org/10.20431/2455-2518.0401004

[51] Ahmed, R.G., 2018n. Maternal thyroid disorders and developing skin dysfunctions. ARC Journal of Dermatology 3(1), 13-17. DOI: http://dx.doi.org/10.20431/2456-0022.0301005

[52] Ahmed, R.G., 2018o. Maternal hypothyroidism-milk ejections: What is the link? ARC Journal of Nutrition and Growth 4(1), 29-33. DOI: http://dx.doi.org/10.20431/2455-2550.0401007

[53] Ahmed, R.G., 2018p. Does maternal antepartum hypothyroidism cause fetal and neonatal hyponatremia?ARC Journal of Diabetes and Endocrinology 4(1), xx-xxx. DOI: http://dx.doi.org/10.20431/2455-5983.0401004

[54] Ahmed, R.G., 2018q. Maternal hypothyroidism and rheumatoid arthritis. International Journal of Research Studies in Medical and Health Sciences Volume 3(2), 1-5. 
[55] Ahmed, R.G., 2018r. Developmental thyroid and skeletal muscle dysfunction.ARC Journal of Diabetes and Endocrinology 4(1), xx-xxx. DOI: http://dx.doi.org/10.20431/2455-5983.0401003.

[56] Ahmed, R.G., 2018s.Hyperthyroidism and renal disorders. ARC Journal of Animal and Veterinary Sciences 4(2), 1-5. DOI: http://dx.doi.org/10.20431/2455-2518.0402001

[57] Ahmed, R.G., Abdel-Latif, M., Ahmed F., 2015a.Protective effects of GM-CSF in experimental neonatal hypothyroidism. International Immunopharmacology 29, 538-543.

[58] Ahmed, R.G., Abdel-Latif, M., Mahdi, E., El-Nesr, K., 2015b. Immune stimulation improves endocrine and neural fetal outcomes in a model of maternofetal thyrotoxicosis. Int. Immunopharmacol. 29, 714-721.

[59] Ahmed, R.G., Davis, P.J., Davis, F.B., De Vito, P., Farias, R.N., Luly, P., Pedersen, J.Z., Incerpi, S., 2013a. Nongenomic actions of thyroid hormones: from basic research to clinical applications. An update. Immunology, Endocrine \& Metabolic Agents in Medicinal Chemistry, 13(1), 46-59.

[60] Ahmed, R.G., El-Gareib, A.W. 2014.Lactating PTU exposure: I- Alters thyroid-neural axis in neonatal cerebellum. Eur. J. of Biol. and Medical Sci. Res. 2(1), 1-16.

[61] Ahmed, R.G., El-Gareib, A.W., 2017.Maternal carbamazepine alters fetal neuroendocrine-cytokines axis. Toxicology 382, 59-66.

[62] Ahmed, R.G., El-Gareib, A.W., Incerpi, S., 2014. Lactating PTU exposure: II- Alter's thyroid-axis and prooxidant-antioxidant balance in neonatal cerebellum. Int. Res. J. of Natural Sciences 2(1), 1-20.

[63] Ahmed, R.G., El-Gareib, A.W., Shaker, H.M., 2018a.Gestational 3, 3', 4, 4', 5-pentachlorobiphenyl (PCB 126) exposure disrupts fetoplacental unit: Fetal thyroid-cytokines dysfunction. Life Sciences 192, 213220.

[64] Ahmed, R.G., Incerpi, S., 2013. Gestational doxorubicin alters fetal thyroid-brain axis. Int. J. Devl. Neuroscience 31, 96-104.

[65] Ahmed, R.G., Incerpi, S., Ahmed, F., Gaber, A., 2013b. The developmental and physiological interactions between free radicals and antioxidant: Effect of environmental pollutants. J. of Natural Sci. Res. 3(13), 74110.

[66] Ahmed, R.G., Walaa G.H., Asmaa F.S., 2018b.Suppressive effects of neonatal bisphenol A on the neuroendocrine system. Toxicology and Industrial Health Journal (in press).

[67] Bakker, S.J., terMaaten, J.C., Popp-Snijders, C., Slaets, J.P., Heine, R.J., Gans, R.O., 2001. The relationship between thyrotropin and low density lipoprotein cholesterol is modified by insulin sensitivity in healthy euthyroid subjects. J ClinEndocrinolMetab 86, 1206-1211.

[68] Benetti-Pinto, C.L., Berini Piccolo, V.R., Garmes, H.M., TeatinJuliato, C.R., 2013. Subclinical hypothyroidism in young women with polycystic ovary syndrome: An analysis of clinical, hormonal, and metabolic parameters. FertilSteril. 99, 588-592.

[69] Beyer, I.W., Karmali, R., Demeester-Mirkine, N., Cogan, E., Fuss, M.J., 1998. Serum creatine kinase levels in overt and subclinical hypothyroidism. Thyroid 8, 1029-1031.

[70] Brenta, G., Berg, G., Arias, P., 2007. Lipoprotein alterations, hepatic lipase activity, and insulin sensitivity in subclinical hypothyroidism: response to L-T (4) treatment. Thyroid 17, 453-60.

[71] Candelotti, E., De Vito, P., Ahmed, R.G., Luly, P., Davis, P.J., Pedersen, J.Z., Lin, H-Y., Incerpi, I., 2015. Thyroid hormones crosstalk with growth factors: Old facts and new hypotheses. Immun., Endoc. \&Metab. Agents in Med. Chem., 15, 71-85.

[72] Caraccio, N., Ferrannini, E., Monzani, F., 2002. Lipoprotein profile in subclinical hypothyroidism: response to levothyroxine replacement, a randomized placebo-controlled study. J ClinEndocrinolMetab 87, 1533-8.

[73] Catargi, B., Parrot-Roulaud, F., Cochet, C., Ducassou, D., Roger, P., Tabarin, A., 2009.Homocysteine, hypothyroidism, and effect of thyroid hormone replacement. Thyroid 9(12), 1163-1166.

[74] Celik, C., Abali, R., Tasdemir, N., Guzel, S., Yuksel, A., Aksu, E., 2012. Is subclinical hypothyroidism contributing dyslipidemia and insulin resistance in women with polycystic ovary syndrome? GynecolEndocrinol. 28, 615-18.

[75] Chubb, S.A., Davis, W.A., Davis, T.M., 2005. Interactions among thyroid function, insulin sensitivity, and serum lipid concentrations: the Fremantle diabetes study. J ClinEndocrinolMetab 90, 5317- 20.

[76] Danese, M.D., Ladenson, P.W., Meinert, C.L., Powe, N.R., 2000. Clinical review 115: effect of thyroxine therapy on serum lipoproteins in patients with mild thyroid failure: a quantitative review of the literature. $\mathrm{J}$ ClinEndocrinolMetab 85, 2993-3001.

[77] De Vito, P., Candelotti, E., Ahmed, R.G., Luly, P., Davis, P.J., Incerpi, S., Pedersen, J.Z., 2015.Role of thyroid hormones in insulin resistance and diabetes.Immun. Endoc.\&Metab. Agents in Med. Chem., 15, 86-93. 
[78] Duman, D., Demirtunc, R., Sahin, S., Esertas, K., 2007. The effects of simvastatin and levothyroxine on intima-media thickness of the carotid artery in female normolipemic patients with subclinical hypothyroidism: a prospective, randomized-controlled study. J Cardiovasc Med (Hagerstown) 8, 1007-11.

[79] Efstathiadou, Z., Bitsis, S., Milionis, H.J., 2001. Lipid profile in subclinical hypothyroidism: is Lthyroxine substitution beneficial? Eur J Endocrinol 145, 705-10.

[80] El-bakry, A.M., El-Ghareeb, A.W., Ahmed, R.G., 2010.Comparative study of the effects of experimentally-induced hypothyroidism and hyperthyroidism in some brain regions in albino rats.Int. J. Dev. Neurosci. 28, 371-389.

[81] El-Ghareeb, A.A., El-Bakry, A.M., Ahmed, R.G., Gaber, A., 2016.Effects of zinc supplementation in neonatal hypothyroidism and cerebellar distortion induced by maternal carbimazole. Asian Journal of Applied Sciences 4(04), 1030-1040.

[82] Erdem, T.Y., Ercan, M., Ugurlu, S., Balci, H., Acbay, O., Gundogdu, S., 2008.Plasma viscosity, an early cardiovascular risk factor in women with subclinical hypothyroidism. ClinHemorheolMicrocirc 38, 21925.

[83] Erem, C., 2006. Blood coagulation, fibrinolytic activity and lipid profile in subclinical thyroid disease: subclinical hyperthyroidism increases plasma factor X activity. ClinEndocrinol (Oxf) 64, 323-9.

[84] Hueston, W.J., Pearson, W.S., 2004. Subclinical hypothyroidism and the risk of hypercholesterolemia. Ann FAM Med 2, 351-5.

[85] Incerpi, S., Hsieh, M-T., Lin, H-Y., Cheng, G-Y., De Vito, P., Fiore, A.M., Ahmed, R.G., Salvia, R., Candelotti, E., Leone, S., Luly, P., Pedersen, J.Z., Davis, F.B., Davis, P.J., 2014. Thyroid hormone inhibition in L6 myoblasts of IGF-I-mediated glucose uptake and proliferation: new roles for integrin avß3. Am. J. Physiol. Cell Physiol. 307, C150-C161.

[86] Iqbal, A., Jorde, R., Figenschau, Y., 2006. Serum lipid levels in relation to serum thyroid-stimulating hormone and the effect of thyroxine treatment on serum lipid levels in subjects with subclinical hypothyroidism: the Tromso Study. J Intern Med 260, 53-61.

[87] Jung, C.H., Sung, K.C., Shin, H.S. 2003. Thyroid dysfunction and their relation to cardiovascular risk factors such as lipid profile, hsCRP, and waist hip ratio in Korea. Korean J Intern Med 18, 146-53.

[88] Knudsen, N., Laurberg, P., Rasmussen, L.B., 2005. Small differences in thyroid function may be important for body mass index and the occurrence of obesity in the population. J ClinEndocrinolMetab 90, 4019-24.

[89] Kung, A.W., Pang, R.W., Janus, E.D., 1995. Elevated serum lipoprotein (a) in subclinical hypothyroidism. ClinEndocrinol (Oxf) 43, 445-449.

[90] Luboshitzky, R., Aviv, A., Herer, P., Lavie, L., 2002. Risk factors for cardiovascular disease in women with subclinical hypothyroidism. Thyroid 12, 421-5.

[91] Milionis, H.J., Efstathiadou, Z., Tselepis, A.D. 2003. Lipoprotein (a) levels and apolipoprotein (a) isoform size in patients with subclinical hypothyroidism: effect of treatment with levothyroxine. Thyroid 13, 3659.

[92] Milionis, H.J., Tambaki, A.P., Kanioglou, C.N., Elisaf, M.S., Tselepis, A.D., Tsatsoulis, A., 2005. Thyroid substitution therapy induces high-density lipoprotein-associated platelet-activating factor-acetylhydrolase in patients with subclinical hypothyroidism: a potential antiatherogenic effect. Thyroid 15, 455-60.

[93] Monzani, F., Caraccio, N., Kozakowa, M., 2004. Effect of levothyroxine replacement on lipid profile and intima-media thickness in subclinical hypothyroidism: a double-blind, placebo controlled study. J ClinEndocrinolMetab 89, 2099-106.

[94] Prasad, R., Kumar, V., 2005. Thyroid hormones increase $\mathrm{Na}^{+}$-Pi co-transport activity in intestinal brush border membrane: role of membrane lipid composition and fluidity. Molecular and Cellular Biochem. 278(1-2), 195-202.

[95] Raza, S.A., Mahmood, N., 2013. Subclinical hypothyroidism: Controversies to consensus. Indian J EndocrinolMetab.17(Suppl 3), S636-S642.

[96] Rizos, C.V., Elisaf, M.S., Liberopoulos, E.N., 2011. Effects of Thyroid Dysfunction on Lipid Profile. The Open Cardiovascular Medicine Journal, 5, 76-84.

[97] Saleh, A.A.S., 2015. Lipid profile and levels of homocysteine and total antioxidant capacity in plasma of rats with experimental thyroid disorders. The Journal of Basic \& Applied Zoology 72, 173-178.

[98] Stone, N.J., 1994. Secondary causes of hyperlipidemia. Med Clin North Am 78, 117-41.

[99] Tanis, B.C., Westendorp, G.J., Smelt, H.M., 1996. Effect of thyroid substitution on hypercholesterolaemia in patients with subclinical hypothyroidism: a reanalysis of intervention studies. ClinEndocrinol (Oxf) 44, 643-9. 
[100]Toruner, F., Altinova, A.E., Karakoc, A., 2008.Risk factors for cardiovascular disease in patients with subclinical hypothyroidism. AdvTher 25, 430-7.

[101]Tsimihodimos, V., Bairaktari, E., Tzallas, C., Miltiadus, G., Liberopoulos, E., Elisaf, M., 1999.The incidence of thyroid function abnormalities in patients attending an outpatient lipid clinic. Thyroid 9, 365368.

[102]Van Herck, S.L.J., Geysens, S., Bald, E., Chwatko, G., Delezie, E., Dianati, E., Ahmed, R.G., Darras, V.M., 2013.Maternal transfer of methimazole and effects on thyroid hormone availability in embryonic tissues. Endocrinol. 218, 105-115.

[103]Walsh, J.P., Bremner, A.P., Bulsara, M.K., 2005. Thyroid dysfunction and serum lipids: a communitybased study. ClinEndocrinol (Oxf) 63, 670-5.

[104]Zhu, X., Cheng, S.Y., 2010.New insights into regulation of lipid metabolism by thyroid hormone. Current Opinion in Endocrinology, Diabetes and Obesity 17(5), 408-413.

Citation: R.G. Ahmed, " Maternal Hypothyroidism-Developing Dyslipidemia: What is the Connection?" ARC Journal of Pharmaceutical Sciences (AJPS), vol. 4, no. 1, p. 1-6, 2018. http://dx.doi.org/10.20431/24551538.0401001

Copyright: (c) 2018 Authors. This is an open-access article distributed under the terms of the Creative Commons Attribution License, which permits unrestricted use, distribution, and reproduction in any medium, provided the original author and source are credited 